\title{
Czy treningi poznawcze mogą być skuteczne?
}

\section{Can cognitive training be effective?}

\begin{abstract}
Following the initial wave of interest in the possibilities of improving human mind efficiency through computerized cognitive training, we are currently experiencing a wave of criticism and disappointment in their effectiveness. This text includes an analysis of the most important studies on the effectiveness of cognitive training (mainly attention and working memory training). The authors attempted to determine the effectiveness of this type of conditioning, inquiring what kind of interventions (and among what types of subjects) can produce satisfactory results. They discuss factors such as target group, training's duration and intensity, type and difficulty level of used tasks, motivation and individual differences of the subjects. The effect of improving both trained functions (near-transfer effect) and other, non-trained capacities (far-transfer effect) was analyzed.
\end{abstract}

Keywords: cognitive training, working memory, attention

\section{Wstęp}

Jak wiele osób jest w pełni zadowolonych ze sprawności swojego intelektu? Popularność, jaką w ciągu ostatnich lat zyskały skomputeryzowane programy trenowania pamięci, uwagi i innych procesów poznawczych, sugeruje, że jest mnóstwo osób nie do końca usatysfakcjonowanych swoją sprawnością poznawczą. Niektórzy chcieliby poprawić pamięć, innym przeszkadza, że ich uwaga wymyka się niekiedy spod kontroli, jeszcze inni marzą o wyższej inteligencji. Prawdopodobnie tego rodzaju potrzeba jest czymś uniwersalnym i towarzyszy ludziom od zarania dziejów, choć zmieniać się może rodzaj zdolności, których mniejsza sprawność przeszkadza najbardziej. Zmieniają się także metody, którymi staramy się osiągnąć zamierzoną poprawę, i sposoby, w jakie szacujemy, czy taka poprawa wystąpiła. Ta ostatnia kwestia jest kontrowersyjna, nierzadko bowiem subiektywnie odczuwalna poprawa nie współgra $\mathrm{z}$ wynikami

1 Artykuł powstał w ramach pracy nad grantem N N106 328239 otrzymanym z Ministerstwa Nauki i Szkolnictwa Wyższego. 
rzetelnych testów psychologicznych. Czy zatem nauka nie ma dobrego rozwiązania dla tych wszystkich, którym zależy na usprawnieniu intelektu? Temat budzi wśród naukowców wiele emocji i rodzi skrajne opinie.

$\mathrm{W}$ toku dziejów poprawę intelektu starano się osiągnąć różnymi sposobami. W opracowaniu dotyczącym trenowania pamięci autorstwa Bąbla i Baran [2011] wyróżnione zostały trzy najczęściej stosowane środki zaradcze: a) dbanie o zdrowy tryb życia, b) środki farmaceutyczne, c) techniki psychologiczne. W tym artykule przyjrzymy się jedynie trzeciej grupie metod, interesować nas będzie przy tym jeden szczególny rodzaj oddziaływań - skomputeryzowane treningi poznawcze. Tego rodzaju techniki poddawano badaniom przynajmniej od lat dziewięćdziesiątych [Diebel i in., 1998], a mniej więcej od 2002 roku ich popularność wśród badaczy zaczęła wzrastać, kosztem metod stosowanych dawniej (treningów grupowych prowadzonych przez nauczyciela lub treningów nagranych na taśmach magnetofonowych). Procesy, które chciano za ich pomocą usprawnić, najczęściej da się opisać w kategoriach uwagi lub pamięci roboczej.

Można odnieść wrażenie, że przełomowym momentem dla treningów poznawczych okazała się publikacja wyników badań zespołu Jaeggi [Jaeggi i in., 2008], w których trenowano studentów za pomocą bardzo wymagającego zadania pamięciowego podwójny N-back. W zadaniu tym należy jednocześnie reagować na bodźce pojawiające się w kanale wzrokowym i słuchowym. Trenujący słyszą ciągi ośmiu liter i jednocześnie widzą na ekranie komputera kwadraty pojawiające się w ośmiu możliwych lokalizacjach wokół centralnie umieszczonego punktu fiksacji. Zadaniem osoby badanej jest stwierdzenie niezależnie w odniesieniu do modalności słuchowej i wzrokowej, czy obecnie prezentowany bodziec jest taki sam jak ten, który pojawił się $n$ elementów wcześniej. W zależności od postępów osób badanych wartość $n$ mogła wzrastać lub maleć, tak aby poziom trudności zadania był dostosowany do możliwości uczestników. Choć trening Jaeggi był stosunkowo krótki (składało się na niego nie więcej niż 19 dni treningowych), przyniósł nie tylko poprawę wykonania zadania treningowego, ale także poprawę wykonania testu inteligencji płynnej. Wynik zainteresował zarówno badaczy inteligencji (stanowił bowiem argument na rzecz tego, że pamięć robocza jest istotną determinantą poziomu inteligencji), jak i psychologów konstruujących narzędzia, które mogłyby usprawnić funkcjonowanie intelektu. W ciągu zaledwie kilku lat, między 2008 a 2012 rokiem, przeprowadzono wiele badań wykorzystujących skomputeryzowane treningi pamięci roboczej jako środek mający poprawić bardziej złożone procesy poznawcze. Niektóre z tych badań przyniosły obiecujące wyniki [Alloway i Alloway, 2009; Beck i in., 2010; Dahlin i in., 2008; McNab i in., 2009; Zhao i in., 2011], inne wiązały się z rozczarowaniem [Brehmer i in., 2011; Chein i Morrison, 2010; Colom i in., 2010; Owen i in., 2010; Richmond i in., 2011; Schmiedek, Lövdén i Lindenberger, 2010].

Gdy jednak zastanawiamy się nad efektywnością treningów poznawczych, warto najpierw odpowiedzieć sobie na pytanie, co przekonałoby nas o ich skuteczności. Treningi poznawcze mają zwykle służyć jednemu z dwóch celów: albo usprawnić procesy, które są bezpośrednio zaangażowane podczas treningu (np. uwagę lub pamięć roboczą), albo poprzez tego rodzaju usprawnienie przynieść zmianę sięgającą bardziej złożonych procesów (np. inteligencji), a nawet wykonania życiowych zadań (jak 
nauka szkolna). Shipstead, Redick i Engle [2010] zaproponowali podział efektów, do których może prowadzić trening poznawczy, na związane z tzw. transferem specyficznym (near-transfer effects) i niespecyficznym (far-transfer effects). Efekt transferu specyficznego ujawnia się w usprawnieniu wykonania zadań treningowych bądź zadań do nich podobnych. Efekty transferu niespecyficznego można zaś wykazać dzięki poprawie wykonania zadań znacznie różniących się od tych wykorzystanych podczas treningu. To ten drugi typ efektów bardziej interesuje badaczy, pozwala bowiem wnioskować, że usprawnione procesy leżą u podłoża (usprawnionych niejako ubocznie) procesów wyższego rzędu, a co więcej - oznacza, że zyskujemy stosunkowo prostą metodę osiągnięcia dosyć szerokiego zakresu zmian poznawczych. Ma to zatem wymiar zarówno teoretyczny, jak i praktyczny.

Należy przyznać, że w przypadku większości treningów poznawczych obserwowane po nich efekty nie dorównują tym, które uzyskano w badaniach zespołu Jaeggi [Jaeggi i in., 2008]. W świetle niejednoznacznych wyników badań, dla zwolenników treningów poznawczych [Gathercole, Dunning i Holmes, 2012] i badaczy wątpiących w ich skuteczność [Melby-Lervåg i Hulme, 2013; Shipstead, Redick i Engle, 2012] nastał być może czas na zmianę głównego pytania. Po entuzjastycznym przyjęciu treningów poznawczych przed rokiem 2010 [np. Sternberg, 2008], ich mocnej krytyce od roku 2012 [np. Shipstead i in., 2012), pojawiają się teksty, które starają się pogodzić dwa sprzeczne stanowiska [Jaeggi i in., 2014]. Płynące z nich przesłanie sugeruje, że interesujące nas dawniej pytanie „Czy treningi poznawcze działają?” należałoby zmodyfikować. Bardziej adekwatne byłoby dociekanie: „Kiedy takie treningi mogą być skuteczne?". Przy tak sformułowanym pytaniu interesować nas będzie to, jaki trening, dla kogo i w jaki sposób aplikowany może doprowadzić do wyników, które mogą wskazywać na jego (realistycznie dookreśloną) skuteczność. W dalszej części artykułu postaramy się na to pytanie odpowiedzieć.

\section{Analiza skuteczności treningów}

\section{Grupa poddana treningowi}

Podstawowym czynnikiem, od którego zależy skuteczność treningów, wydaje się rodzaj grupy objętej oddziaływaniem. Treningi uwagi najlepiej sprawdzają się wtedy, gdy objęte są nimi osoby, u których występują deficyty danej funkcji spowodowane urazami głowy, chorobami czy procesami starzenia. Dotychczas najwięcej badań nad treningami uwagi przeprowadzono na dzieciach z diagnozą ADHD [np. Kerns, Eso i Thomson, 1999; Shalev, Tsal i Mevorach, 2007; Tucha i in., 2011]. W przypadku gdy trenują osoby dorosłe lub dzieci typowo się rozwijające, efekty oddziaływań są znacznie mniejsze [Dowsett i Livesey, 2000; Dörrenbächer i in, 2014; Karbach i Kray, 2009; Rueda i in., 2005; Rueda, Checa i Combita, 2012]. Dobrym przykładem będą tutaj badania Karbach i Kray (2009) nad treningiem przerzutności uwagi, aplikowanym uczestnikom $z$ trzech grup wiekowych (8-10, 18-26 i 62-76 lat). Co prawda po treningach wszyscy poprawili swoje wyniki w zadaniach mierzących przerzutność uwagi, jednak poprawa ta była najbardziej widoczna u dzieci i osób starszych, czyli 
przedstawicieli grup wiekowych, w których ten aspekt uwagi funkcjonuje najsłabiej, co widoczne było już w preteście.

Grupą zdrowych osób, u których treningi uwagi przynoszą najbardziej widoczne rezultaty, są małe dzieci, u których mechanizmy uwagi nie zdążyły się jeszcze w pełni wykształcić. Trening może przynosić u nich rezultaty podobne do dojrzewania mózgu. Świadczą o tym wyniki szeroko cytowanych badań Ruedy [Rueda i in., 2005], która wraz ze współpracownikami przeprowadziła badania mające na celu ustalenie, jak trening uwagi może wpływać na rozwój sieci uwagi zarządczej u dzieci. W jej badaniach wzięły udział dzieci czteroletnie i sześcioletnie, które poddano sesjom treningowym (pięć razy w ciągu dwóch lub trzech tygodni). W ich trakcie wykonywały zadania mające trenować m.in. antycypację, różnicowanie bodźców, radzenie sobie z konfliktem czy hamowanie. Mimo niewielkiej liczby treningów okazało się, że dzieci ze wszystkich grup eksperymentalnych poprawily swoje wyniki w testach uwagi i inteligencji płynnej. Poprawa ta była widoczna nie tylko w behawioralnych wskaźnikach testu, takich jak czasy reakcji, ale również na poziomie neuronalnym. Dane z EEG pokazały bowiem, że trening daje podobne efekty jak dojrzewanie mózgu. Wzorzec aktywności mózgu trenowanych czterolatków stał się taki jak u dzieci sześcioletnich niepoddawanych treningowi, a dzieci sześcioletnie po treningu miały zapis EEG podobny do osób dorosłych.

W przypadku treningów pamięci roboczej sytuacja wydaje się jeszcze bardziej złożona, a jedyny pewny wniosek dotyczący ich efektywności zalecałby daleko posuniętą ostrożność. Najbardziej pewna wydaje się możliwość uzyskania poprawy w zakresie trenowanych zadań lub zadań bardzo do nich podobnych, czyli tzw. transferu specyficznego [Chein i Morrison, 2010; Dahlin i in., 2008; Jaeggi i in., 2010; Klingberg, Forssberg i Westerberg, 2002; Li i in., 2008; McNab i in., 2009; Owen i in., 2010]. Jednakże już nawet kwestia tego, czy trening poprawia ogólną sprawność pamięci roboczej, czy jedynie te jej aspekty, które są angażowane przez zadania, jest kwestią kontrowersyjną. Badań, w których tego rodzaju zmianę udało się wykazać wprost i za pomocą rzetelnych metod (m.in. korzystając nie tylko z zadań stosowanych do treningu), jest stosunkowo niewiele [Seidler i in., 2010], a nierzadko takiej zmiany nie udało się zaobserwować pomimo podjętych prób [Brehmer i in., 2011; Li i in., 2008; Owen i in., 2010; Richmond i in., 2011]. Wydaje się jednak, że niektóre z treningów pamięci roboczej wpłynęły nie tylko na poprawę $\mathrm{w}$ zakresie pamięci roboczej, ale usprawniły także bardziej złożone procesy. Szczególnie obiecujące wydają się treningi przeprowadzone wśród grup klinicznych i subklinicznych. W grupie dzieci z diagnozą ADHD trening oparty na zadaniach zakresu (COGMED) poprawiał nie tylko pamięć roboczą [Beck i in., 2010; Holmes i in., 2009], lecz również inteligencję [Klingberg, Forssberg i Westerberg, 2002; Klingberg i in., 2005], a nawet osłabiał objawy ADHD [Beck i in., 2010; Klingberg i in., 2005]. Najmniej obiecujące pod tym względem wydają się treningi dedykowane zdrowym dorosłym osobom. Poprawę inteligencji udało się wykazać zaledwie kilka razy, w tym w kontrowersyjnych badaniach Jaeggi [Jaeggi i in., 2008] oraz Olesen, Westerberga i Klingberga [2004]. W obu tych badaniach można się dopatrzeć wielu metodologicznych niedociągnięć - zespołowi Jaeggi zarzucano między innymi brak aktywnej grupy kontrolnej, stosowanie różnych testów do oceny inteligencji w poszczególnych grupach czy wreszcie trudności 
w replikacji tego wyniku przez innych badaczy [Redick i in., 2013; Chooi i Thompson, 2012], natomiast $w$ badaniach Olesen poprawę inteligencji wykazano $\mathrm{w}$ grupie młodych dorosłych (20-23 lata) złożonej zaledwie z trzech osób. Zdecydowana większość raportów z badań tego typu nie wskazuje na możliwość uzyskania po treningu transferu sięgającego inteligencji [Brehmer i in., 2011; Chein i Morrison, 2010; Colom i in., 2010; Owen i in., 2010; Richmond i in., 2011; Seidler i in., 2010].

Problematyczną kwestią pozostaje skuteczność treningów w grupie dzieci typowo się rozwijających. Niekiedy bowiem udaje się wykazać, że poprawa po treningu sięga nie tylko poziomu ogólnej sprawności pamięci roboczej [St Clair-Thompson i in., 2010; Thorell i in., 2008], ale też bardziej złożonych procesów. Zhao i współpracownicy [Zhao i in., 2011] zaobserwowali po treningu poprawę wykonania testu inteligencji płynnej. Tego rodzaju zmianę wykazano także w innych badaniach [Jaeggi i in., 2011], ale tylko u tych dzieci, które osiągnęly największy postęp treningowy, bądź u tych, które uczestniczyły w treningu najmniej skoncentrowanym w czasie [Wang, Zhou i Shah, 2014]. Zdarzało się jednak, że tak ogólnych efektów poprawy inteligencji nie udawało się wykazać [Ang i in., 2015; Bergman Nutley i in., 2011; Pugin i in., 2015; Shavelson i in., 2008; Thorell i in., 2008]. Nie brak jednak raportów donoszących, że trening pamięci roboczej może usprawnić przebieg bardziej specyficznych procesów, jak czytanie [Loosli i in., 2012], a nawet nauka szkolna w zakresie języka i matematyki [Holmes i Gathercole, 2014; Goldin i in., 2014]. Wydaje się zatem, że ocena skuteczności tego rodzaju oddziaływań wymaga uwzględnienia nie pojedynczych czynników, ale ich wzajemnej interakcji. Być może tak właśnie warto byłoby podejść do ogólnej oceny efektywności treningów poznawczych, nie tylko tych nakierowanych na usprawnienie pamięci roboczej.

\section{Długość i intensywność treningów}

Głównym czynnikiem wpływającym na skuteczność treningów powinna być oczywiście ich długość i intensywność. Mimo to ten aspekt treningów nie został dotąd gruntownie przebadany. W treningach uwagi niektórzy badacze aplikują swoim badanym krótkie i intensywne treningi (np. osiem sesji w ciągu tygodnia [Mozolic $\mathrm{i}$ in., 2011]), u innych równie mała liczba sesji jest rozciągnięta na dłuższy czas (np. pięć sesji treningowych na trzy lub cztery tygodnie u Ruedy i zespołu [2005]), jeszcze inni preferują zdecydowanie dłuższe treningi (20 sesji na przestrzeni czterech lub pięciu tygodni [Krejtz, 2012]).

Nieco bardziej jednoznaczne wnioski co do wpływu czasu treningu na efektywność oddziaływania płyną z badań nad treningiem pamięci roboczej. Okazuje się, że wraz z liczbą sesji treningowych wzrasta siła efektów treningu [np. Jaeggi i in., 2008]. Znaczenie ma jednak nie tylko sama liczba sesji, ale także ich rozłożenie w czasie. Gdy porównano ze sobą efektywność różnych programów treningowych złożonych z 20 sesji (każda trwająca 20 minut), w których sesje rozłożono na 2, 5, 10 lub 20 dni, okazało się, że najbardziej rozciągnięte w czasie ćwiczenia były najskuteczniejsze [Wang, Zhou i Shah, 2014].

Mimo tych danych trudno o konkluzywne wnioski, bo choć każdy z treningów prowadził do transferu specyficznego, obecność transferu niespecyficznego była 
sprawdzana stosunkowo rzadko (wyjątek mogą stanowić badania Wang, Zhou i Shah [2014]). Rzadko dokonywano także pomiaru odroczonego. Tym samym bardzo trudno ocenić, jaki czas treningu jest optymalny dla uzyskania poprawy trenowanych i nietrenowanych funkcji oraz dla ewentualnego utrzymywania się tych zmian w czasie.

\section{Poziom trudności zadań}

Kolejnym czynnikiem, który zdaje się istotnie wpływać na skuteczność treningów poznawczych, jest adekwatne zróżnicowanie poziomu trudności programu, tak aby odpowiadał on aktualnej kompetencji osoby ćwiczącej (czyli tzw. trening adaptacyjny). Już w 2010 roku wykazano, że tylko ten rodzaj oddziaływań może doprowadzić do transferu niespecyficznego [por. Klingberg, 2010]. Efekt ten replikowano wielokrotnie, stosując treningi pozbawione modyfikacji poziomu trudności jako treningi dla tzw. aktywnej grupy kontrolnej. Istotna wydaje się jednak nie tylko zmiana stopnia trudności zadań, ale także płynność pod tym względem, aby zadanie nie było nigdy ani za trudne, ani za łatwe dla trenującego. Nieco inne światło na to zagadnienie rzucają wyniki badań von Bastian i Eschen [2016]. Badaczki kwestionują założenie, iż jedynie odpowiednie dopasowanie poziomu trudności do kompetencji umożliwia efektywność treningu, istotne jest ich zdaniem samo umożliwienie ćwiczeń na różnorodnych poziomach trudności. Zwracają uwagę, że badania, na których oparto przekonanie o kluczowej roli adaptacji poziomu trudności, porównywały najczęściej trening adaptacyjny $\mathrm{z}$ treningiem bez adaptacji, który bazował jedynie na najprostszych wersjach analogicznych zadań. Von Bastian i Eschen porównały skuteczność trzech form treningu pamięci roboczej: a) treningu adaptacyjnego, w którym poziom trudności zadań był dopasowany do zmieniającej się kompetencji gracza; b) treningu, w którym poziom trudności był ustalany losowo; c) treningu, w którym gracz sam decydował o zmianie poziomu trudności zadania, a wyniki porównano z grupą kontrolną. Każdy z treningów doprowadził do poprawy wykonania zadań treningowych (a stopień poprawy był we wszystkich grupach zbliżony), ale żaden z nich nie pozwolił na ujawnienie się efektów transferu dalekiego na poziomie rozumowania.

Pojawiają się także inne doniesienia sugerujące, że adaptacyjność poziomu trudności, czyli jego płynne dostosowywanie do zmieniającej się kompetencji gracza, może wcale nie być kluczowe dla osiągnięcia efektów zmiany po treningu. W badaniach [Minear i in., 2016] porównano skuteczność czterech form treningu: a) zadań wzrokowo-przestrzennych typu $\mathrm{N}$-back $\mathrm{w}$ wersji $\mathrm{z}$ adaptacją poziomu trudności; b) zadań tego samego typu, ale bez adaptacji poziomu; c) zadań zakresu (angażujących werbalne funkcje pamięci roboczej); d) strategiczną grę wideo czasu rzeczywistego (real-time strategy video game). Jedynym efektem, który udało się zaobserwować, była poprawa wykonania różnego rodzaju zadań typu N-back po treningu wzrokowo-przestrzennym. Co zaskakujące, taka poprawa wystąpiła zarówno po programie z modyfikacją poziomu trudności, jak i bez niej. 


\section{Typ zadań}

Może się zatem wydawać, że na skuteczność treningu w jeszcze większej mierze niż forma zadań wpływa sam rodzaj tych zadań. Analiza badań z zakresu skuteczności treningów poznawczych zdaje się skłaniać do kilku bardziej szczegółowych wniosków na ten temat. Przede wszystkim należałoby zaznaczyć, że choć transfer specyficzny, czyli poprawę w zakresie wykonywanych zadań, obserwowano zarówno po treningach opartych na zadaniach angażujących funkcje uwagi, jak i po ćwiczeniach angażujących pamięć roboczą, to jednak ten drugi typ zadań znacznie częściej pozwalał uzyskać efekty transferu niespecyficznego. Efekty, jakie można uzyskać po treningu, zależą także od tego, czy sam trening jest nakierowany na zwiększenie wydolności procesów zaangażowanych w wykonywanie zadań ( $t z w$. core training), czy też raczej na usprawnienie strategii wykonywania określonego rodzaju zadań (tzw. strategy training [por. Morrison i Chein, 2011]). Ten drugi typ treningów umożliwia wyćwiczenie procedur, które pozwalają na bardziej efektywne wykonywanie określonego rodzaju zadań. Treningi wydolności mają bardziej ambitny cel, jakim jest zwiększenie wydajności samych procesów leżących u podstaw wykonywania tego rodzaju zadań. Treningi strategii są bardzo mocno zależne od specyficznych cech zadań oferowanych w trakcie treningu, przez co ich efekty rzadko przekładają się na szerszy zakres sprawności. W przypadku drugiego rodzaju zadań taki transfer udaje się uzyskać częściej, choć dużą rolę odgrywa również to, na jakich dokładnie procedurach oparto wykorzystane zadania i jak dobrze dopasowano je do użytkowników treningu [por. Morrison i Chein, 2011]. Przykładowo, w treningach pamięci roboczej poprawę w zakresie kompetencji wiązanych $\mathrm{z}$ inteligencją obserwowano zazwyczaj po treningach opartych na zadaniach angażujących silnie funkcje zarządcze, np. po treningu funkcji nadzorowania (supervision) w badaniach von Bastian i Oberauera [2013] lub po treningu aktualizowania informacji [Wang, Zhou i Shah, 2014]. Jeśli jednak oddziaływaniu podlegały dzieci, których uwaga nie funkcjonowała w sposób w pełni sprawny (np. dzieci z diagnozą ADHD), poprawę inteligencji można było zaobserwować także po treningach opartych na zadaniach angażujących w znacznej mierze procesy przechowywania informacji w obrębie pamięci roboczej, czyli zadaniach zakresu [Klingberg, Forssberg i Westerberg, 2002; Klingberg i in., 2005]. Należy jednak podkreślić, że zagadnienie jest bardziej złożone, ponieważ nie zawsze udawało się zaobserwować transfer daleki, nawet po zadaniach angażujących funkcje zarządcze [Ang i in., 2015]. Co więcej, niektórzy badacze są zdania, że część dowodów mających przemawiać za możliwością tego rodzaju transferu jest mało wiarygodna, np. Moody [2009] przekonuje, że słynne badania zespołu Jaeggi [Jaeggi i in., 2008], w których po treningu zaobserwowano poprawę wykonania testu rozumowania niewerbalnego, pozwoliły co najwyżej wykazać poprawę w zakresie szybkości mentalnej, ale nie inteligencji.

\section{Rola różnic indywidualnych i motywacji osób badanych}

Na wyniki treningów, zwłaszcza u osób zdrowych, duży wpływ mogą mieć różnice indywidualne. Bardzo ciekawe badania przeprowadzili Studer-Luethi, Jaeggi, Buschkuehl i Perrig [2012], pokazując, jak cechy osobowości, takie jak neurotyzm 
i sumienność, mogą wpływać na skuteczność treningu pamięci roboczej. Osoby o niskim poziomie neurotyzmu więcej zyskiwały na treningu $\mathrm{z}$ użyciem podwójnego zadania N-back, podczas gdy dla osób $\mathrm{z}$ wysokim nasileniem tej cechy korzystniejszy był trening $\mathrm{z}$ pojedynczym zadaniem tego rodzaju. Osoby o wysokim nasileniu sumienności również więcej skorzystały $\mathrm{z}$ treningu wykorzystującego pojedyncze zadanie, choć poprawa ujawniła się tylko $\mathrm{w}$ zadaniach mierzących transfer specyficzny. Autorzy sugerują, że osoby sumienne rozwinęły w trakcie treningu zdolności, które były specyficzne dla trenowanego zadania, dlatego efekt poprawy nie ujawnił się na poziomie transferu niespecyficznego. W innych badaniach Studer-Luethi, Bauer i Perrig [2016] wykazali znaczący wpływ tzw. wytężonej kontroli, będącej formą samoregulacji (effortful control, tłumaczenie za Brzezińską i Nowotnik, 2012), zarówno na wyniki w zadaniach treningowych, jak i w testach kryterialnych. Znajomość cech osobowości i zdolności do samoregulacji osób badanych powinna zatem odgrywać decydującą rolę przy przydziale osób badanych do grup treningowych i doborze zadań.

Kolejnym czynnikiem różnicującym osoby biorące udział w treningach jest ich przekonanie dotyczące natury inteligencji. Część ludzi uważa, że poziom inteligencji jest czymś stałym i w żaden sposób nie można na niego wpływać. Inni natomiast sądzą, że jest to właściwość, która może podlegać pewnym modyfikacjom, np. pod wpływem doświadczenia. Osoby, których wyniki w teście Cognitive Abilities Scale [Dweck, 2000] świadczą o przynależności do tej drugiej grupy, rzadziej wycofują się $\mathrm{z}$ treningów i łatwiej podtrzymują swoje zaangażowanie $\mathrm{w}$ wykonywanie wymagających zadań poznawczych [Blackwell, Trzesniewski i Dweck, 2007].

Kolejną ważną zmienną jest bez wątpienia wyjściowy poziom zdolności poznawczych osób badanych oraz sposób, w jaki badani sami je oceniają. Osoby, które zgłaszają się do grup treningowych, zwykle wypadają gorzej w skalach samoopisowych dotyczących ich funkcjonowania poznawczego niż osoby zgłaszające się do grup kontrolnych [Jaeggi i in., 2014]. Chociaż w zadaniach poznawczych w pretestach obie grupy osiągają podobne wyniki, subiektywne przekonanie dotyczące własnej sprawności intelektualnej u osób z grup eksperymentalnych sprawia, że są bardziej zmotywowane do treningów i częściej je kończą. Co więcej, jeśli wyniki uzyskiwane (przed treningiem) przez osobę badaną $\mathrm{w}$ testach inteligencji oraz teście badającym chęć do podejmowania wysiłku poznawczego (Need for Cognition Scale [Cacioppo i Petty, 1982]) są wysokie, zwiększa się szansa, że weźmie ona udział we wszystkich treningach i pomiarach oraz będzie zaangażowana w zadania podczas każdej sesji.

Różnice indywidualne mogą znacząco wpływać na motywację osób badanych, która jest kolejnym ważnym predykatorem skuteczności treningów. Ponownie wydaje się, że trening działa najlepiej w przypadku osób najbardziej zmotywowanych do wykonywania zadań treningowych. Przykład mogą stanowić osoby zmagające się z deficytami poznawczymi, które częściej traktują ćwiczenia jako niezbędny element swojej rehabilitacji pozwalającej wrócić do sprawnego funkcjonowania. Szczególnie istotne wydaje się zatem podtrzymywanie zaangażowania w trening osób zdrowych w młodszym wieku. Jednym ze sposobów jest zadbanie o omawiany wyżej optymalny poziom trudności stosowanych zadań treningowych. Przy zbyt trudnych zadaniach uczestnicy badań przeżywają najczęściej frustrację i szybko przestają się starać, a przy 
zadaniach zbyt prostych zwyczajnie się nudzą [Jaeggi i in., 2014]. Utrzymanie zainteresowania ćwiczących jest istotne także z tego względu, że jedynie w tych okolicznościach można liczyć na ich pełne zaangażowanie poznawcze w wykonywanie zadań. Ono zaś umożliwia ćwiczenie blisko granicy wydolności procesów poznawczych, co wydaje się kluczowe dla efektywności treningu.

By zapewnić zaangażowanie w trening, zadania powinny mieć atrakcyjną, ale nie nadmiernie interesującą formę (szczególnie w zakresie tych elementów, które nie są podstawową składową zadania, ale stanowią dystrakcję), aby nie odciągnąć uwagi trenujących od samego zadania, co mogłoby spowolnić uzyskanie postępu treningowego [Katz i in., 2014]. Obecnie większość stosowanych w treningach zadań nie przypomina już surowego podwójnego zadania N-back z badań Jaeggi [Jaeggi i in., 2008] i wyglądem jest zbliżona do komercyjnych gier komputerowych. Badacze starają się utrzymywać motywację osób badanych na wysokim poziomie m.in. poprzez stosowanie różnych systemów wzmocnień czy podawanie informacji zwrotnej, dzięki której osoba badana kontroluje swoje postępy. Co ciekawe, coraz rzadziej stosuje się finansowe wynagradzanie osób badanych za udział w treningu, ponieważ wysoka zapłata sprawia, że badani kierują się jedynie motywacją zewnętrzną, co obniża ich postępy w zadaniach treningowych oraz szanse na uzyskanie transferu [Anguera i in., 2012; Chooi i Thompson, 2012; Redick i in., 2013; Kundu i in., 2013]. Warto podkreślić, że pomysł na monitorowanie zaangażowania trenujących pojawił się w badaniach nad treningami poznawczymi stosunkowo niedawno, a część badaczy sugeruje, że to właśnie różnice $\mathrm{w}$ motywacji osób badanych mogą odpowiadać za różnice w skuteczności treningów we wcześniejszych badaniach, tym bardziej że dowiedziono, iż progres w zadaniach treningowych jest pozytywnie skorelowany z poprawą wykonania zadań kryterialnych [Jaeggi i in., 2008, 2011].

Co zatem znaczy, że trening działa?

Po zapoznaniu się z powyższą analizą możemy powrócić do głównego pytania: w jakich okolicznościach treningi poznawcze okazują się skuteczne? Pamiętajmy przy tym, że skuteczność oceniamy z rozróżnieniem na efekty transferu specyficznego i niespecyficznego. Odpowiedź na to pytanie wymaga odrębnego ujęcia treningów uwagi i pamięci roboczej. W przypadku treningów uwagi transfer specyficzny zwykle udawało się uzyskać, ale postępy niestety nie utrzymywały się w czasie [np. Conklin i in., 2016]. Transfer niespecyficzny udawało się natomiast zaobserwować właściwie wyłącznie w grupach klinicznych lub u dzieci, u których uwaga nie była jeszcze w pełni rozwinięta. Transfer ten ograniczał się najczęściej do innych, nietrenowanych aspektów uwagi. W pojedynczych badaniach zanotowano poprawę w zakresie szybkości przetwarzania, funkcji zarządczych lub inteligencji. Mimo podejmowanych prób [np. Mozolic i in., 2011] w wyniku treningu uwagi nie udało się poprawić pamięci roboczej ani inteligencji.

W przypadku treningów pamięci roboczej transfer niespecyficzny udaje się zaobserwować częściej i choć dzisiaj trudno upatrywać w nich metody pozwalającej podnieść poziom inteligencji [Brehmer i in., 2011; Chein i Morrison, 2010; Colom i in., 2010; Owen i in., 2010; Richmond i in., 2011; Seidler i in., 2010] u osób dorosłych, to być może u dzieci (po uzyskaniu zadowalającego stopnia postępu treningowego i przy odpowiednio rozłożonym w czasie oddziaływaniu) jest to możliwe. Wydaje się 
przy tym, że choć w grupach klinicznych można osiągnąć taką poprawę, wykorzystując zadania zakresu [Klingberg i in., 2005; Klingberg, Forssberg i Westerberg, 2002], to u dzieci rozwijających się typowo lepiej sprawdzają się ćwiczenia silniej angażujące funkcje wykonawcze pamięci roboczej [Jaeggi i in., 2011; Wang, Zhou i Shah, 2014; Zhao i in., 2011). Mimo to kwestia transferu niespecyficznego w przypadku tego typu oddziaływań, w szczególności zaś objaśnienie jego mechanizmu, pozostaje nadal problemem otwartym.

\section{Podsumowanie}

Podsumowując - wydaje się, że rozczarowanie związane $\mathrm{z}$ treningami poznawczymi wiąże się ze zbyt dużymi nadziejami, które na początku w nich pokładano. Większość badań pokazuje, że dbając o zaangażowanie osób badanych i stosując odpowiednio dobrane zadania o zróżnicowanym poziomie trudności, aplikowane w adekwatnych odstępach czasu, jesteśmy w stanie usprawnić trenowaną funkcję. Nie można natomiast oczekiwać, że zmiany tego rodzaju, w szczególności u zdrowych osób dorosłych, przełożą się na poprawę o znacznie szerszym zakresie lub utrzymają się długo po zaniechaniu ćwiczeń. Należy wyraźnie podkreślić, że skuteczny trening musi być odpowiednio dobrany do grupy docelowej (a być może nawet do indywidualnych charakterystyk każdej osoby), w związku z czym nie można oczekiwać spektakularnych efektów po mało zindywidualizowanych treningach eksperymentalnych ani tym bardziej po stosowanych masowo treningach komercyjnych. Osoby zainteresowane użytkowaniem tego typu programów treningowych powinny zaś zachować ostrożność i powstrzymać nadzieje, że prosty trening poznawczy może usprawnić każdą zdolność i poprawić wykonanie zadań życia codziennego, nawet wtedy gdy na ćwiczenia poświęcimy zaledwie kilka minut dziennie. Zadanie dla badaczy polega natomiast na tym, aby jeszcze precyzyjniej określić, jakie charakterystyki programów treningowych przekładają się na zwiększoną skuteczność treningów, czego rzeczywiście możemy po takich ćwiczeniach oczekiwać (a czego nie), jak trenować, aby czas poświęcany na trening przekładał się na uzyskiwane efekty, i jak zadbać o to, aby trenujący mieli ochotę wkładać w te ćwiczenia wystarczająco dużo wysiłku. Wydaje się zatem, że badania nad treningami poznawczymi, zapoczątkowane na gruncie eksperymentalnej psychologii poznawczej, wchodzą w fazę, w której korzystna może się okazać współpraca interdyscyplinarna.

\section{BIBLIOGRAFIA}

Alloway, T.P., Alloway, R.G. (2009). The efficacy of working memory training in improving crystallized intelligence. Nature Precedings, hdl:10101/npre.2009.3697.1.

Ang, S.Y., Lee, K., Cheam, F., Poon, K., Koh, J. (2015). Updating and working memory training: immediate improvement, long-term maintenance, and generalisability to non-trained tasks. Journal of Applied Research in Memory and Cognition, 4(2), 121-128. 
Anguera, J.A., Bernard, J.A., Jaeggi, S.M., Buschkuehl, M., Benson, B.L., Jennett, S., ... Seidler, R.D. (2012). The effects of working memory resource depletion and training on sensorimotor adaptation. Behavioural Brain Research, 228(1), 107-115.

Bąbel, P., Baran, B. (2011). Trening pamięci: projektowanie, realizacja, techniki i ćwiczenia. Warszawa: Difin.

Beck, S.J., Hanson, C.A., Puffenberger, S.S., Benninger, K.L., Benninger, W.B. (2010). A controlled trial of working memory training for children and adolescents with ADHD. Journal of Clinical Child \& Adolescent Psychology, 39(6), 825-836.

Bergman Nutley, S., Söderqvist, S., Bryde, S., Thorell, L.B., Humphreys, K., Klingberg, T. (2011). Gains in fluid intelligence after training non-verbal reasoning in 4-year-old children: A controlled, randomized study. Developmental Science, 14(3), 591-601.

Blackwell, L.S., Trzesniewski, K.H., Dweck, C.S. (2007). Implicit theories of intelligence predict achievement across an adolescent transition: A longitudinal study and an intervention. Child Development, 78(1), 246-263.

Brehmer, Y., Rieckmann, A., Bellander, M., Westerberg, H., Fischer, H., Bäckman, L. (2011). Neural correlates of training-related working-memory gains in old age. Neuroimage, 58(4), $1110-1120$.

Brzezińska, A.I., Nowotnik, A. (2012). Funkcje wykonawcze a funkcjonowanie dziecka w środowisku przedszkolnym i szkolnym. Edukacja, 1, 61-74.

Cacioppo, J.T., Petty, R.E. (1982). The need for cognition. Journal of Personality and Social Psychology, 42, 116-131.

Chein, J.M., Morrison, A.B. (2010). Expanding the mind's workspace: Training and transfer effects with a complex working memory span task. Psychonomic Bulletin \& Review, 17(2), 193-199.

Chooi, W.T., Thompson, L.A. (2012). Working memory training does not improve intelligence in healthy young adults. Intelligence, 40(6), 531-542.

Colom, R., Quiroga, M.Á., Shih, P.C., Martínez, K., Burgaleta, M., Martínez-Molina, A., ... Ramírez, I. (2010). Improvement in working memory is not related to increased intelligence scores. Intelligence, 38(5), 497-505.

Conklin, H.M., Ashford, J.M., Clark, K.N., Martin-Elbahesh, K., Hardy, K.K., Merchant, T.E., Ogg, R.J., Jeha, S., Huang, L., Zhang, H. (2016). Long-term efficacy of computerized cognitive training among survivors of childhood cancer: A single-blind randomized controlled trial. Journal of Pediatric Psychology, 41(6).

Dahlin, E., Neely, A.S., Larsson, A., Bäckman, L., Nyberg, L. (2008). Transfer of learning after updating training mediated by the striatum. Science, 320(5882), 1510-1512.

Diebel, A., Feige, C., Gedschold, J., Goddemeier, A., Schulze, F., Weber, P. (1998). Computer assisted training of attention and concentration with healthy children. Praxis der Kinderpsychologie und Kinderpsychiatrie, 47(9), 641-656.

Dowsett, S.M., Livesey, D.J. (2000). The development of inhibitory control in preschool children: Effects of "executive skills" training. Developmental Psychobiology, 36(2), 161-174.

Dörrenbächer, S., Müller, P.M., Tröger, J., Kray, J. (2014). Dissociable effects of game elements on motivation and cognition in a task-switching training in middle childhood. Frontiers in Psychology, 5.

Dweck, C.S. (2000). Self-theories: Their Role in Motivation, Personality, and Development. London-New York: Psychology Press.

Gathercole, S.E., Dunning, D.L., Holmes, J. (2012). Cogmed training: Let's be realistic about intervention research. Journal of Applied Research in Memory and Cognition, 1(3), 201-203.

Goldin, A.P., Hermida, M.J., Shalom, D.E., Costa, M.E., Lopez-Rosenfeld, M., Segretin, M.S., ... Sigman, M. (2014). Far transfer to language and math of a short software-based gaming intervention. Proceedings of the National Academy of Sciences, 111(17), 6443-6448.

Holmes, J., Gathercole, S.E. (2014). Taking working memory training from the laboratory into schools. Educational Psychology, 34(4), 440-450. 
Holmes, J., Gathercole, S.E., Place, M., Dunning, D.L., Hilton, K.A., Elliott, J.G. (2009). Working memory deficits can be overcome: Impacts of training and medication on working memory in children with ADHD. Applied Cognitive Psychology, 24(6), 827-836.

Jaeggi, S.M., Buschkuehl, M., Jonides, J., Shah, P. (2011). Short- and long-term benefits of cognitive training. Proceedings of the National Academy of Sciences, 108(25), 10081-10086.

Jaeggi, S.M., Buschkuehl, M., Jonides, J., Perrig, W.J. (2008). Improving fluid intelligence with training on working memory. Proceedings of the National Academy of Sciences, 105(19), 68296833.

Jaeggi, S.M., Buschkuehl, M., Shah, P., Jonides, J. (2014). The role of individual differences in cognitive training and transfer. Memory \& Cognition, 42(3), 464-480.

Jaeggi, S.M., Studer-Luethi, B., Buschkuehl, M., Su, Y.F., Jonides, J., Perrig, W.J. (2010). The relationship between n-back performance and matrix reasoning - implications for training and transfer. Intelligence, 38(6), 625-635.

Karbach, J., Kray, J. (2009). How useful is executive control training? Age differences in near and far transfer of task-switching training. Developmental Science, 12(6), 978-990.

Katz, B., Jaeggi, S., Buschkuehl, M., Stegman, A., Shah, P. (2014). Differential effect of motivational features on training improvements in school-based cognitive training. Frontiers in $\mathrm{Hu}$ man Neuroscience, 8, 242.

Kerns, K.A., Eso, K., Thomson, J. (1999). Investigation of a direct intervention for improving attention in young children with ADHD. Developmental Neuropsychology, 16(2), 273-295.

Klingberg, T. (2010). Training and plasticity of working memory. Trends in Cognitive Sciences, 14(7), 317-324.

Klingberg, T., Fernell, E., Olesen, P.J., Johnson, M., Gustafsson, P., Dahlstrom, K. (2005). Computerized training of working memory in children with ADHD - a randomized, controlled trial. Journal of the American Academy of Child and Adolescent Psychiatry, 44(2), 177-186.

Klingberg, T., Forssberg, H., Westerberg, H. (2002). Training of working memory in children with ADHD. Journal of Clinical and Experimental Neuropsychology, 24(6), 781-791.

Krejtz, I. (2012). Korepetycje poznawcze. Rola pamięci roboczej i kontroli uwagi w przewidywaniu osiagnięć szkolnych. Warszawa: Wydawnictwo Akademickie Sedno.

Kundu, B., Sutterer, D.W., Emrich, S.M., Postle, B.R. (2013). Strengthened effective connectivity underlies transfer of working memory training to tests of short-term memory and attention. The Journal of Neuroscience, 33(20), 8705-8715.

Li, S.C., Schmiedek, F., Huxhold, O., Röcke, C., Smith, J., Lindenberger, U. (2008). Working memory plasticity in old age: Practice gain, transfer, and maintenance. Psychology and Aging, 23(4), 731.

Loosli, S.V., Buschkuehl, M., Perrig, W.J., Jaeggi, S.M. (2012). Working memory training improves reading processes in typically developing children. Child Neuropsychology, 18(1), 62-78.

McNab, F., Varrone, A., Farde, L., Jucaite, A., Bystritsky, P., Forssberg, H., Klingberg, T. (2009). Changes in cortical dopamine D1 receptor binding associated with cognitive training. Science Signalling, 323(5915), 800-802.

Melby-Lervåg, M., Hulme, C. (2013). Is working memory training effective? A meta-analytic review. Developmental Psychology, 49(2), 270-291.

Minear, M., Brasher, F., Guerrero, C.B., Brasher, M., Moore, A., Sukeena, J. (2016). A simultaneous examination of two forms of working memory training: Evidence for near transfer only. Memory \& Cognition, 1-24.

Moody, D.E. (2009). Can intelligence be increased by training on a task of working memory? Intelligence, 37, 327-328.

Morrison, A.B., Chein, J.M. (2011). Does working memory training work? The promise and challenges of enhancing cognition by training working memory. Psychonomic Bulletin \& Review, 18(1), 46-60. 
Mozolic, J.L., Long, A.B., Morgan, A.R., Rawley-Payne, M., Laurienti, P.J. (2011). A cognitive training intervention improves modality-specific attention in a randomized controlled trial of healthy older adults. Neurobiological Aging, 32(4), 655-668.

Olesen, P.J., Westerberg, H., Klingberg, T. (2004). Increased prefrontal and parietal activity after training of working memory. Nature Neuroscience, 7(1), 75-79.

Owen, A.M., Hampshire, A., Grahn, J.A., Stenton, R., Dajani, S., Burns, A.S., ... Ballard, C.G. (2010). Putting brain training to the test. Nature, 465(7299), 775-778.

Pugin, F., Metz, A.J., Stauffer, M., Wolf, M., Jenni, O.G., Huber, R. (2015). Working memory training shows immediate and long-term effects on cognitive performance in children. F1000Research, 3 .

Redick, T.S., Shipstead, Z., Harrison, T.L., Hicks, K.L., Fried, D.E., Hambrick, D.Z., ... Engle, R.W. (2013). No evidence of intelligence improvement after working memory training: A randomized, placebo-controlled study. Journal of Experimental Psychology: General, 142(2), 359.

Richmond, L.L., Morrison, A.B., Chein, J.M., Olson, I.R. (2011). Working memory training and transfer in older adults. Psychology and Aging, 26(4), 813.

Rueda, M.R., Checa, P., Combita, L.M. (2012). Enhanced efficiency of the executive attention network after training in preschool children: immediate changes and effects after two months. Developmental Cognitive Neuroscience, 2, S192-S204.

Rueda, M.R., Rothbart, M.K., McCandliss, B.D., Saccomanno, L., Posner, M.I. (2005). Training, maturation, and genetic influences on the development of executive attention. Proceedings of the National Academy of Sciences of the United States of America, 102(41), 14931-14936.

Schmiedek, F., Lövdén, M., Lindenberger, U. (2010). Hundred days of cognitive training enhance broad cognitive abilities in adulthood: findings from the COGITO study. Frontiers in Aging Neuroscience, 2.

Seidler, R.D., Bernard, J.A., Buschkuehl, M., Jaeggi, S., Jonides, J., Humfleet, J. (2010). Cognitive training as an intervention to improve driving ability in the older adult. University of Michigan.

Shalev, L., Tsal, Y., Mevorach, C. (2007). Computerized progressive attentional training (CPAT) program: effective direct intervention for children with ADHD. Child Neuropsychology, 13(4), 382-388

Shavelson, R.J., Yuan, K., Alonzo, A.C., Klingberg, T., Andersson, M. (2008). On the impact of computerized cognitive training on working memory and fluid intelligence. W: D.C. Berliner, H. Kuppermintz (eds.), Contributions of Educational Psychology to Changing Institutions, Environments, and People (s. 1-11). New York: Routledge.

Shipstead, Z., Redick, T.S., Engle, R.W. (2010). Does working memory training generalize? Psychologica Belgica, 50(3-4), 3-4.

Shipstead, Z., Redick, T.S., Engle, R.W. (2012). Is working memory training effective? Psychological Bulletin, 138(4), 628-654.

Sternberg, R.J. (2008). Increasing fluid intelligence is possible after all. Proceedings of the National Academy of Sciences, 105(19), 6791-6792.

St Clair-Thompson, H., Stevens, R., Hunt, A., Bolder, E. (2010). Improving children's working memory and classroom performance. Educational Psychology, 30(2), 203-219.

Studer-Luethi, B., Bauer, C., Perrig, W.J. (2016). Working memory training in children: Effectiveness depends on temperament. Memory \& Cognition, 44(2), 171-186.

Studer-Luethi, B., Jaeggi, S.M., Buschkuehl, M., Perrig, W.J. (2012). Influence of neuroticism and conscientiousness on working memory training outcome. Personality and Individual Differences, 53(1), 44-49.

Thorell, L.B., Lindqvist, S., Bergman Nutley, S., Bohlin, G., Klingberg, T. (2008). Training and transfer effects of executive functions in preschool children. Developmental Science, 12(1), $106-113$. 
Tucha, O., Tucha, L., Kaumann, G., König, S., Lange, K.M., Stasik, D., ... Lange, K.W. (2011). Training of attention functions in children with attention deficit hyperactivity disorder. ADHD Attention Deficit and Hyperactivity Disorders, 3(3), 271-283.

von Bastian, C.C., Eschen, A. (2016). Does working memory training have to be adaptive? Psychological Research, 80(2), 181-194.

von Bastian, C.C., Oberauer, K. (2013). Distinct transfer effects of training different facets of working memory capacity. Journal of Memory and Language, 69(1), 36-58.

Wang, Z., Zhou, R., Shah, P. (2014). Spaced cognitive training promotes training transfer. Frontiers in Human Neuroscience, 8, 217.

Zhao, X., Wang, Y., Liu, D., Zhou, R. (2011). Effect of updating training on fluid intelligence in children. Chinese Science Bulletin, 56(21), 2202-2205. 